\title{
Financial inequality nexus and Islamic banking
}

\author{
Diyah Putriani ${ }^{1}$, Prastowo ${ }^{2 *}$ \\ Department of Economics, International Islamic University Malaysia, Selangor, Malaysia \\ Faculty of Economics, Universitas Islam Indonesia, Yogyakarta, Indonesia \\ *Corresponding author: prastowo@uii.ac.id
}

\section{Keywords: \\ Islamic Banks, Income \\ Inequality, Financial Depth, \\ Financial Stability \\ Article History \\ Received : 19 May 2019 \\ Accepted : 8 July 2019 \\ Published: 29 July 2019 \\ DOI: \\ 10.20885/JEKI.vol5.iss2.art1}

JEL:

B26, O15, C33, Z12

\begin{abstract}
This research aims to investigate the role of Islamic banking on income inequality reduction. The data of this research spans from 2010 to 2015 and investigate 49 Islamic banks from 13 selected countries. This study employs Panel data EGLS. To compare with other macroeconomic variable, this research involves GDP Per capita, and inflation as control variable. The estimation result shows that financial depth measured by total customer deposit to GDP ratio has negative relationship with income inequality. It perhaps occurs when there is an increase in income, customers prefer to save their additional income in Islamic banks. As customers increase their deposits, Islamic banks enlarge its financing on the prospect entrepreneurs. These entrepreneurs, afterwards, may expand their business and create new jobs. More new jobs offer means more people get stable income and as a result may reduce income inequality in the society.
\end{abstract}

\section{Introduction}

All countries around the world deal with the problem of income inequality. A report from Organization for Economic Cooperation and Development (OECD) shows that in the last 30 years the disparity between the rich and poor is at its highest level in majority of OECD countries. That is, the richest $10 \%$ of the population in the OECD region have 9.5 times higher income than the poorest $10 \%$. In addition, the Gini index had raised by about 3 points from 0.29 (in the middle of 1980) to 0.32 (between 2011 and 2012).

Many literatures hypothesize that financial development may reduce income distribution gap by allowing low income households to access financing from banking sector. According to the report from World Bank (2015), there are around 2 billion people (or 38\% of population) in the world do not get benefit from financial services and about $73 \%$ of poor people are unbanked due to unaffordable cost, geography distance, and other constraints which hinders them to open the bank account. In other words, financial sector is considered as an exclusive system in a certain society. By allowing low income group access financial institutions, they are expected to have better opportunity to attain education, hire more workers, or do new business as well as improve their skills and eventually increase their labor productivity. The expectation of ultimate condition drives a rise in the total factor productivity and a $\mathrm{s}$ a result promotes sustainable economic development. In other words, financial development (through widening financial access) improve income distribution particularly in the low level income household and hence can be a potential alternative policy to reduce poverty in transition economies (Čihák et al., 2013).

In the other hand, current study shows that income gap distribution is caused by money and debt created by banking and financial system. In this sense, Blair (2010) critically reviews the role of financial innovation on credit and leverage in the creation of income and wealth distribution. Financial innovation leads to financial institution creating a large amount of leverage to supply large amount of lending and to have large amount of loans so that the demand for credit can be provided. As its consequences, there will be too much debt as well as credit which thereby triggers asset bubbles and makes the economy faces high risk to crisis. Asset bubbles are the main problem as the destructive effects on the distribution of income and wealth as well as the allocation of capital in the real economy. Here, a significant increase in asset prices could lead to the delusion that the financial sector forms value for the whole economy, especially for those who invest and trade in capital market. At this point, bubbles are likely to redistribute income and wealth more for those invests in financial market and hence the distribution of income tends to be widened.

Nowadays, Islamic banking industry expands rapidly. Across 13 selected countries ${ }^{1}$, total asset in 49 Islamic banks reach more than US\$ 12 million in 2010 and increase doubled (US\$ 27.4 million) in 2015. It means during 5 years its total asset has growth almost 120\%. In addition, total customer deposits also

\footnotetext{
${ }^{1}$ Selected countries can be refereed in the methodology part. 
significantly rise up to $145 \%$ from US\$ 6.1 million in 2010 to US\$14.9 million in 2015 . Considering this fact and previous literature on the relationship financial development and income distribution, this research is proposed to empirically investigate the impact of financial development in Islamic banking on income distribution.

To examine the impact of banking on income inequality, there are some indicators of banking development. Literatures of banking development are fundamentally explored under financial development which discusses both financial institutions and financial market development. Many empirical studies use private credit to GDP as the indicator of the whole financial development; however, the World Bank considers this proxy is one of financial depth measure. In other words, measures of financial development in the previous literatures do not comprehensively cover all indicators. Seven and Coskun (2016) even specifically address that one of the major problems in the empirical research on finance inequality nexus is to select main variable to measure finance development. Therefore, this research applies banking development indicators of the World Bank which offers a $4 \times 2$ matrix characteristics and indicator of financial development.

A group of the World Bank's economists such as Čihák et al. (2013) develop a measure of characteristic of financial system. This measure is also functioned to assess the development in the financial sector. Financial development takes place when instruments, markets and intermediaries in financial sector facilitate the impacts of information, enforcement and transaction costs. Financial sector development, thus, respectively brings job at offering the main role of the financial sector in the economy.

The financial sector is classified into two sectors which are financial institution and financial market. There are four characteristics of financial system which include financial depth, access, efficiency and stability whereby each characteristic has certain indicator or proxy (Cihák, 2013).

The first characteristic is financial depth. Financial depth is to measure size of financial institution and markets. Most of literature use ratio of private credit to GDP as the proxy of financial development. The reason is due to ratio of private credit can figure to what extent private sector is able to access financial sector in order to meet their financial needs. According to World Bank in World Development Indicator (2005), private credit provided by banking sector covers all credit to all industries on a gross basis. In other words, the private credit does not include credit issued by central banks, credit issued for government and its agencies and state-owned enterprises. (Seven and Coskun, 2016) further explain that private credit to GDP can be a financial development indicator in developing countries where financing and borrowing becomes the main business activities in financial sector. This is due to the stock market sill underdeveloped, and in some cases does not exist.

Level of the ratio of private credit to GDP has two contradict implications to the economy. First, private credit to GDP has a significant effect to reduce income inequality as well as poverty. Second, a high ratio of private credit to GDP might cause banking crisis like what happened in 2008 in 8 countries (Ireland, Spain, Portugal, Cyprus, Netherlands, United Kingdom, Switzerland, and Luxembourg).

Another indicator is total banking asset to GDP which also become one of variable indicator of financial depth in the Global Financial Development Database published by World Bank. Total banking asset to GDP variable is argued to have more complete measure of size of the financial sector due to it covers both credit to private sector and credit to government and bank asset. The data, however, is not available in all countries, thus only small number of empirical research use this variable.

One of the indicators financial market depths is represented by both bond and stock market. The most widely used indicators are the sum of stock market capitalization to GDP and the outstanding volume of private debt securities to GDP. Stock market capitalization to GDP is a variable to represent size of the stock market, while the outstanding volume of private debt securities to GDP is to represent size of bond market.

The second characteristic is financial access. Financial access used to measure of degree to which every individual is able to access and do use financial product and services. Recently, the issue of financial access is discussed in the area of financial inclusion. Financial access variable is commonly represented by number of banks accounts per 1,000 adults. Meanwhile, a measure of financial access on stock and bond market, previous study uses market concentration; that is greater level of concentration means higher difficulties to access for new comer as well as small issuer.

The third characteristics is efficiency. Efficiency measure efficiency on financial intermediaries and markets in performing intermediary function and facilitating transaction. It is a cost of credit intermediation. In the literature, return on assets and return on equity are both common proxies used for financial institution, while for stock market usually use turnover ratio. Turnover ratio is the ratio of annual turnover in the stock market to its capitalization.

The fourth charachteristic is stability. Stability measure the stability on financial institutions and markets. It relates on how banks may overcome the risk of creditor bankruptcy case and other economic shock. The four measure components of financial development summarized into $4 \times 2$ matrix framework describe in Table 1 . 
Table 1. 4x2 Matrix Characteristic and Indicator Development of Financial Sector

\begin{tabular}{|c|c|c|}
\hline & Financial Institution & $\begin{array}{r}\text { Financial Market } \\
\end{array}$ \\
\hline 竞 & $\begin{array}{l}\text { - Private credit to GDP } \\
\text { - Financial institutions' assets to GDP } \\
\text { - M2 to GDP } \\
\text { - Deposits to GDP } \\
\text { - Gross value-added of the financial sector to } \\
\text { GDP }\end{array}$ & $\begin{array}{l}\text { - Stock market capitalization to GDP plus outstanding } \\
\text { domestic private debt securities to GDP } \\
\text { - Private debt securities to GDP } \\
\text { - Public debt securities to GDP } \\
\text { - International debt securities to GDP } \\
\text { - Stock market capitalization to GDP } \\
\text { - Stocks traded to GDP }\end{array}$ \\
\hline 总 & $\begin{array}{l}\text { - Accounts per thousand adults (commercial } \\
\text { bank) } \\
\text { - Branches per } 100,000 \text { adults (commercial } \\
\text { banks) } \\
\text { - \% of people with a bank account } \\
\text { - \% of firms with lie of credit (all firms) } \\
\text { - \% of fimrs with line of credit (small firms) }\end{array}$ & $\begin{array}{l}\text { - Percentage of market capitalization outside of top } 10 \\
\text { largest companies } \\
\text { - Percentage of value traded outside of top } 10 \text { traded } \\
\text { companies } \\
\text { - Government bond yields ( } 3 \text { month and } 10 \text { years) } \\
\text { - Ratio of domestic to total debt securities } \\
\text { - Ratio of private to total debt securities (domestic) } \\
\text { - Ratio of new corporate bond issues to GDP }\end{array}$ \\
\hline 总 & $\begin{array}{l}\text { - Net interest margin } \\
\text { - Lending-deposits spread } \\
\text { - Non-interest income to total income } \\
\text { - Overhead costs (\% of total assets) } \\
\text { - Profitability (return on assets, return on equity) } \\
\text { - Boone indicator (or Herfindahl or H-statistics) }\end{array}$ & $\begin{array}{l}\text { - Turnover ratio (turnover/capitalization) for stock } \\
\text { - Pricket } \\
\text { - Private information trading } \\
\text { - Price impact } \\
\text { - Liquidity/transaction costs } \\
\text { - Quoted bid-ask spread for government bonds } \\
\text { - Turnover of bonds (private, public) on securities exchange } \\
\text { - Settlement efficiency }\end{array}$ \\
\hline 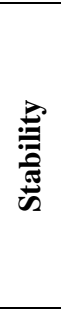 & $\begin{array}{l}\text { - Z-score (or distance to default) } \\
\text { - Capital adequacy ratios } \\
\text { - Asset quality ratios } \\
\text { - Liquidity ratios } \\
\text { - Other (net foreign exchange position to capital } \\
\text { etc.) }\end{array}$ & $\begin{array}{l}\text { - Volatility (standard deviation / average) of stock price } \\
\text { index, sovereign bond index } \\
\text { - Skewness of the index (stock price, sovereign bond) } \\
\text { - Vulnerability to earnings manipulation } \\
\text { - Price/earnings ratio } \\
\text { - Duration } \\
\text { - Ratio of short-term to total bonds (domestic, international) } \\
\text { - Correlation with major bond returns (German, US) }\end{array}$ \\
\hline
\end{tabular}

There are some empirical works using cross section analysis and show that financial development may help to promote income distribution amongst the people. By applying GMM procedures, (Elmi and Ariani, 2011) show that financial development has a significantly negative relationship with income inequality in the case of Middle East and the North Africa (MENA) countries for the period 2004-2008. It suggests that financial development may improve income distribution. The regression shows that an increase of $1 \%$ in financial development turns out a decline in income inequality by about $0.13 \%$. To accelerate the reduction of inequality, the regression also suggests increasing openness and schooling years (as a representation for human capital). Similar technique and result are also found in 29 urban provinces in China (Liang, 2006), African countries (Batuo, Guidi, and Mlambo, 2010), 59 province in Vietnam (Chu and Le, 2012), 103 province in Italy (Onofrio and Murro, 2013).

In addition, some studies investigate single country using time series analysis that have been investigated and find that financial development contribute to reduce income inequality. By employing the long run relationship using Auto Regressive Distributed Lag (ARDL) and short run relationship using Error Correction Model (ECM) methodologies, both (Shahbaz and Islam, 2011) and (Shahbaz et al. 2015) take case study in Pakistan, meanwhile Saitti, et.al (2015) observe in Kazakhstan. Similarly, (Baligh and Piraee, 2013) employ Unrestricted Error Correction Model (UECM) to investigate financial income inequality nexus for the period 1973 to 2010 in Iranian economy. Zhang and Chen (2015) employ SVAR analysis and observe the case of China for the period 1978 to 2013.

In the other hand, many empirical works argue that income inequality exists due to the limited access of low-income families has a to financial sector. This means that financial sector has an important role to reduce income inequality. Theoretically, financial inclusion is a concept whereby financial sector provides services which simply can be used by customer and other economic agent to do their business. The basic financial services include credit, savings mobilization, risk management, and insurance (Mohieldin et al. 2012). These services in the long term are expected to promote growth as well as reduce income inequality(Akimov, Wijeweera, and Dollery, 2006; Kenourgios and Samitas, 2007; Levine, 2003). Park and Shin (2015) in this regard, address financial development must be accompanied by financial inclusion to foster inclusive growth. It 
is thus expected that sustainable growth and productivity will be faster attained if all individual in the society is able to access basic financial services, especially for small medium enterprises.

According to the report from World Bank (2015), there are around 2 billion people (or 38\% of population) in the world do not benefit financial services and about $73 \%$ of poor people are unbanked due to unaffordable cost, geography distance, and other constraints which causes them are not eligible to open bank account. This means that financial sector is considered as an exclusive system in some cases of certain society. This issue later brings an idea to put forward financial inclusion as a concept to promote prosperity.

The introduction of financial inclusion in 1990s to overcome these matters is now broadly accepted by multinational organizations as well as central banks around the world. This legal acceptance and support is expected to enhance the acceleration of financial sector to improve the level of economic growth. Fundamentally, financial inclusion aims to embrace all individual (society) of such country, particularly in developing countries, by delivering financial service at affordable cost. It implies that better ability to access financial services means that better opportunity for entrepreneur to get new capital to enlarge their business. Bigger financial inclusion is expected to contribute to eradicate poverty, economic growth and higher employment, greater agricultural production as well as food security, women empowerment, better health insurance and etc.

Empirical studies observed by Ayyagari, Beck, and Hoseini (2013) and (Agnello and Sousa 2011) support that the higher access for the poor to credit enables them to expand their small business and thus may invest in education and health care for their child. This would eventually help the poor to come out of the poverty and hence reduce the level of income gap. Their research takes case study in India.In short, the negative relationship financial sector and income inequality can be benefitted as a sector to reach inclusive growth and its ultimate goal is to reduce income inequality.

Kumhof and Ranciere (2010) also address that a higher demand on loans from bottom group will also affect to a greater size of financial industry to increase credit. The economy hence will vulnerable to economic crisis. As shown in figure (2.6) the U.S. financial sector grew quickly during 1981 and 2007. That is, the ratio of private credit (90\%) more than two times higher than GDP (210\%). The share of financial sector in GDP increases two times (from 4 to $8 \%$ ). A significant rise on loans leads the economy become more exposes to crisis. Many asserted that what happened during financial crisis in 2007 was due to excessive loans.

Similiarly, Jauch and Watzka (2015) empirically investigates the relationship between financial development and income inequality across 138 developed and developing countries during 1960 to 2008 . By employing fixed effect panel data and GMM approach, they find that financial development raises income inequality within countries. This perhaps happens due to excessive finance that promote rent extraction which eventually triggers income inequalities. More specifically, the result shows that an increase of credit by $10 \%$ triggers to an increase by about 0.22 in the Gini coefficient. By employing Auto Regressive Distributed Lag (ARDL, Law and Tan (2009) find the same result is in the case of Malaysia.

\section{Research Method}

The econometric model of this research is built to model Islamic banking and its impact on income distribution. Financial market indicators will be excluded in the model due to the research is focused on the area of Islamic banking development. Thus, financial development in this research specifically refers to the development in the Islamic banking sector.

To examine the relationship between Islamic banks and income distribution, the econometric model is built as follows.

$$
\mathrm{GINI}_{\mathrm{i}, \mathrm{t}}=\alpha+\beta_{0} \text { FINDEV }_{\mathrm{i}, \mathrm{t}}+\beta_{1} \mathrm{GDPC}_{\mathrm{i}, \mathrm{t}}+\beta_{2} \text { INFLATION }_{\mathrm{i}, \mathrm{t}}+\mu_{\mathrm{i}}+\varepsilon_{\mathrm{i}, \mathrm{t}}
$$

where GINI is the Gini coefficient; FINDEV denotes a vector of two characteristic of financial sectors which are financial depth and bank stability. These two financial variables are chosen due to it has direct impact on income inequality, while efficiency element is directly related to the performance of the banks. Financial access element is excluded from the model because no data are available.

GDPC represents the real GDP per capita, meanwhile INFLATION is inflation rate. Subscripts $i$ and $t$ are index of Islamic bank $i$ and time, respectively. In addition, econometric model above involves an unobservable specific Islamic bank effect $\mu$ and an error term $\varepsilon$. To compare the effect with other variable, GDPC and INFLATION are involved in the model as control variable. The selection of control variables is based on the most widely variables treated as control variable. In addition, the selection of variables as well as proxies is based on the most widely available as suggested by the World Bank ${ }^{2}$. Table 2 shows the measure of variables.

\footnotetext{
${ }^{2}$ Research work written by Cihák, et.al. (2015)
} 
Table 2. Measures of Variables

\begin{tabular}{llll}
\hline Variable & Symbol & Measure & Sources \\
\hline Income Inequality & & & \\
\hline Gini Index & GINI & Gini index data & $\begin{array}{l}\text { World Bank, Standardized World } \\
\text { Income Inequality Database (SWIID), } \\
\text { United Nation, OECD, Statistic Bureau } \\
\text { (Singapore, Indonesia, Malaysia) }\end{array}$ \\
\hline Financial Development & & & \\
\hline Financial Depth & FD & Total customer deposit to GDP ratio & Bankscope \\
Financial Stability & FS & $\begin{array}{l}\text { Equity to asset ratio (Capital } \\
\text { adequacy ratio) }\end{array}$ & Bankscope \\
\hline Control Variables & & & \\
\hline GDP per capita & GDPC & $\begin{array}{l}\text { GDP per capita PPP (constant 2011 } \\
\text { international \$) } \\
\text { the annual growth rate of the GDP }\end{array}$ & World Bank \\
Inflation Rate & inplicit deflator. & World Bank \\
\hline
\end{tabular}

To examine finance and income inequality nexus in Islamic banking, the model of this research is based on a panel data set covering Islamic banking cross countries. The span period cover 2010 to 2015 and involve 49 Islamic banks from 13 various countries as case study. Graph 1 below shows Gini index from 13 selected countries, i.e. Bangladesh, Egypt, Indonesia, Iran, Iraq, Malaysia, Pakistan, the Philippines, Qatar, Senegal, Singapore, and United Kingdom. Here, Egypt, Malaysia and the Philippines are three countries reaching highest Gini index in 2012 up to around 0.46 . However, all countries are basically facing the problem of high-income inequality as shown in Figure 1.

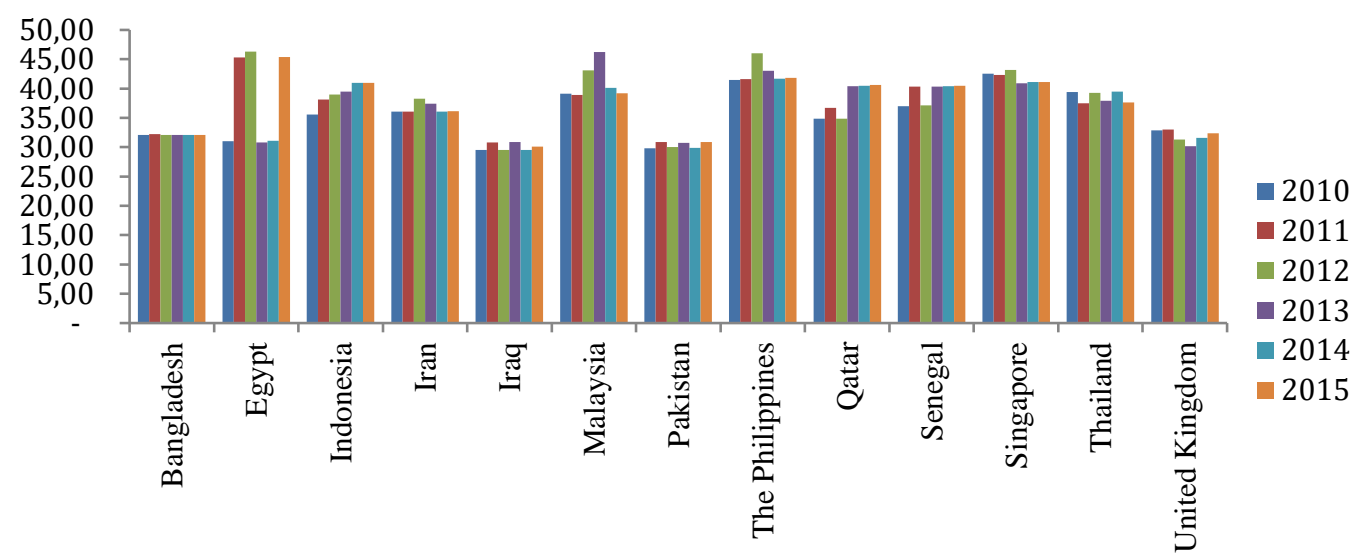

Sources: World Bank, SWIID, United Nation, OECD, Statistic Bureau. Authors'calculation.

Figure 1. Gini Index in 13 Selected Countries

Table 3. Number of Islamic Banks

\begin{tabular}{lclc}
\hline \multicolumn{1}{c}{ Country } & No. of banks & \multicolumn{1}{c}{ Country } & No. of banks \\
\hline Bangladesh & 7 & Qatar & 2 \\
Egypt & 3 & Senegal & 1 \\
Indonesia & 12 & Singapore & 1 \\
Iran & 1 & Thailand & 1 \\
Iraq & 1 & The Philippines & 1 \\
Malaysia & 12 & United Kingdom & 2 \\
Pakistan & 5 & Total & 49 Islamic banks \\
\hline
\end{tabular}

Malaysia and Indonesia are two countries with has many Islamic banks, i.e. 12 banks (Table 3). Both their people and government support the existence of Islamic banks in their economic activity. Thus, this is perhaps the reason why these two countries have more Islamic banks compared to other countries. In this research, there are 49 Islamic banks to be observed. 
In addition, the development of Islamic banks in 13 selected countries shows better progress year to year. This condition is depicted on the growth of total asset (Graph 2). Iran, Malaysia, Qatar, Indonesia and Egypt are 5 countries which show significant progress on accruing total assets. Specifically, on average during 2010-2015, total asset in these five countries reach US\$ 133.4 million (Iran), US\$ 67.2 million (Malaysia), US\$ 22.3 million (Qatar), US\$11.7 million (Indonesia) and US\$ 8.8 million (Egypt).

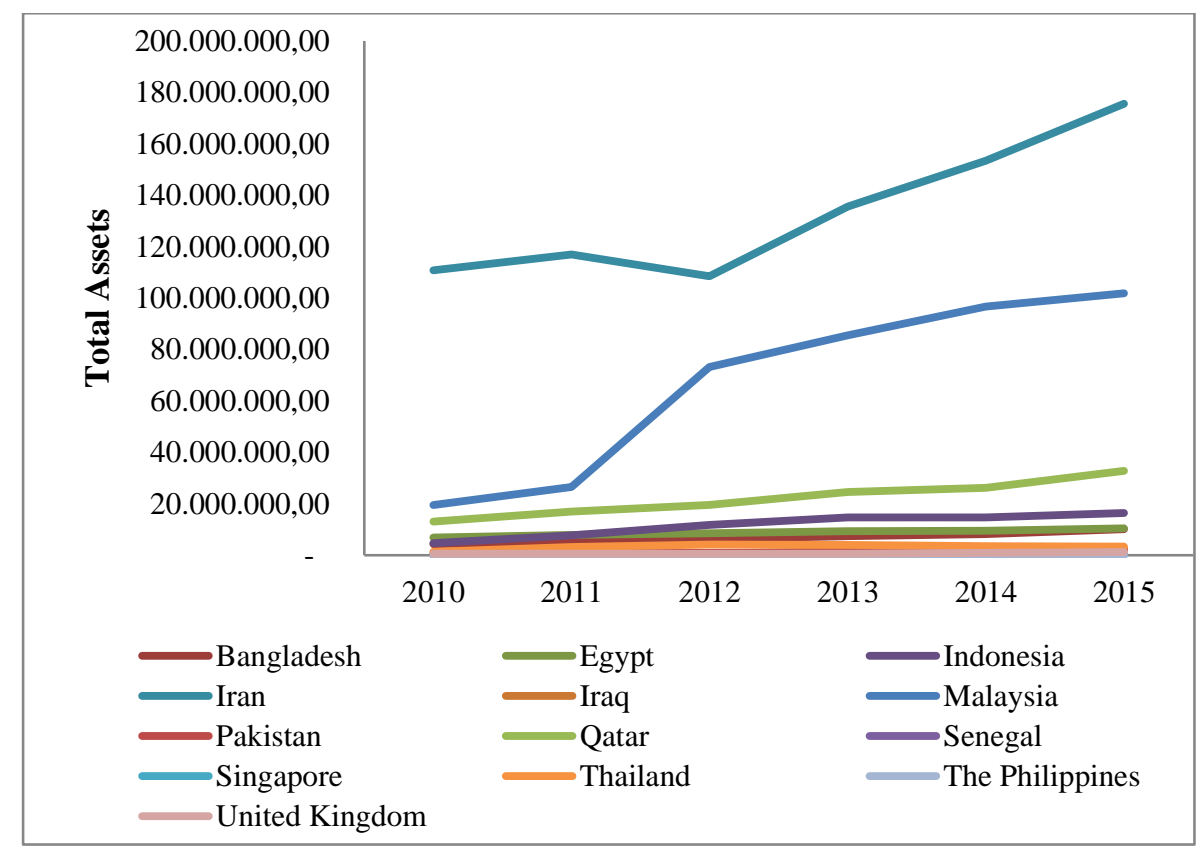

Source: Bankscope. Authors'calculation

Figure 2. Total Assets in 13 Selected Countries

\section{Result discussion}

Table 4 shows descriptive statistics data of each variables. It shows that the mean of Gini index, inflation of financial depth, stability and GDP amongst selected country are about 36.91 and 5.51, 0.0058, 0.5, and 26395.31, respectively. Meanwhile, the standard deviation is arrond 4.90, 0.0123, 0.2816, 34438.62 and 6.27 for Gini index, financial depth, stability, GDP and inflation, respectively.

Table 4. Descriptive Statistics

\begin{tabular}{lccccc}
\hline & GINI & FD & FS & GDPC & INF \\
\hline Mean & 36.91 & 0.0058 & 0.5017 & 26395.31 & 5.51 \\
Maximum & 46.30 & 0.0695 & 1.0013 & 129349.9 & 39.30 \\
Minimum & 29.53 & 0.0000 & 0.0010 & 2442.729 & -2.40 \\
Std. Dev. & 4.90 & 0.0123 & 0.2816 & 34438.62 & 6.27 \\
Observations & 78 & 78 & 78 & 78 & 78 \\
\hline
\end{tabular}

Panel EGLS results show that FD or total customer deposit to GDP ratio has negative impact on Gini index. Recall that financial depth is to estimate the size of market and financial institution. More specifically, if there is an increase of ratio of total customer deposit to GDP by $1 \%$, the Gini Index will decrease about $0.01 \%$ (Table 5). This condition might happen when people experience an increase in their income, however their marginal propensity to save (MPS) is higher than their marginal propensity to consume (MPC) or MPS > MPC. An increase of total customer deposit will raise total amount of financing. In this case, Islamic bank might distribute more financing to new entrepreneurs for business expansion. This condition can be seen from Figure 3 and Figure 4 below showing that there is an increase in total customer deposits contemporaneously a rise in gross loan. An increase in business activity hence might create new jobs or even higher level of wage which then minimize income inequality. 
Tabel 5. Panel EGLS Result

\begin{tabular}{llccc}
\hline Variabels & \multicolumn{3}{c}{$(1)$} & $(2)$ \\
\hline FD $(\log )$ & coefficient & t-Statictic & coefficient & t-Statictic \\
FS $(\log )$ & -0.0108 & {$[-3.133]^{* * *}$} & -0.0105 & {$[-2.969]^{* * *}$} \\
GDPC $(\log )$ & -0.0058 & {$[-1.324]$} & -0.0056 & {$[-1.272]$} \\
INF & 0.1316 & {$[2.296]^{* *}$} & 0.1474 & {$[2.285]^{* *}$} \\
Constant & & & 0.001 & {$[1.0414]$} \\
\hline Observation & 2.2590 & {$[4.0727]^{* * *}$} & 2.1058 & {$[3.5253]^{* * *}$} \\
R-squared & 78 & & 78 & \\
\hline
\end{tabular}

Note: Values in brackets are t-stat. $* * *, * *$, and * refer to significant at $\mathrm{p}<0.01, \mathrm{p}<0.05$, and $\mathrm{p}<0.10$ respectively.

Source: Bankscope, World Bank, SWIID, United Nation, OECD, Statistic Bureau. Authors'calculation.

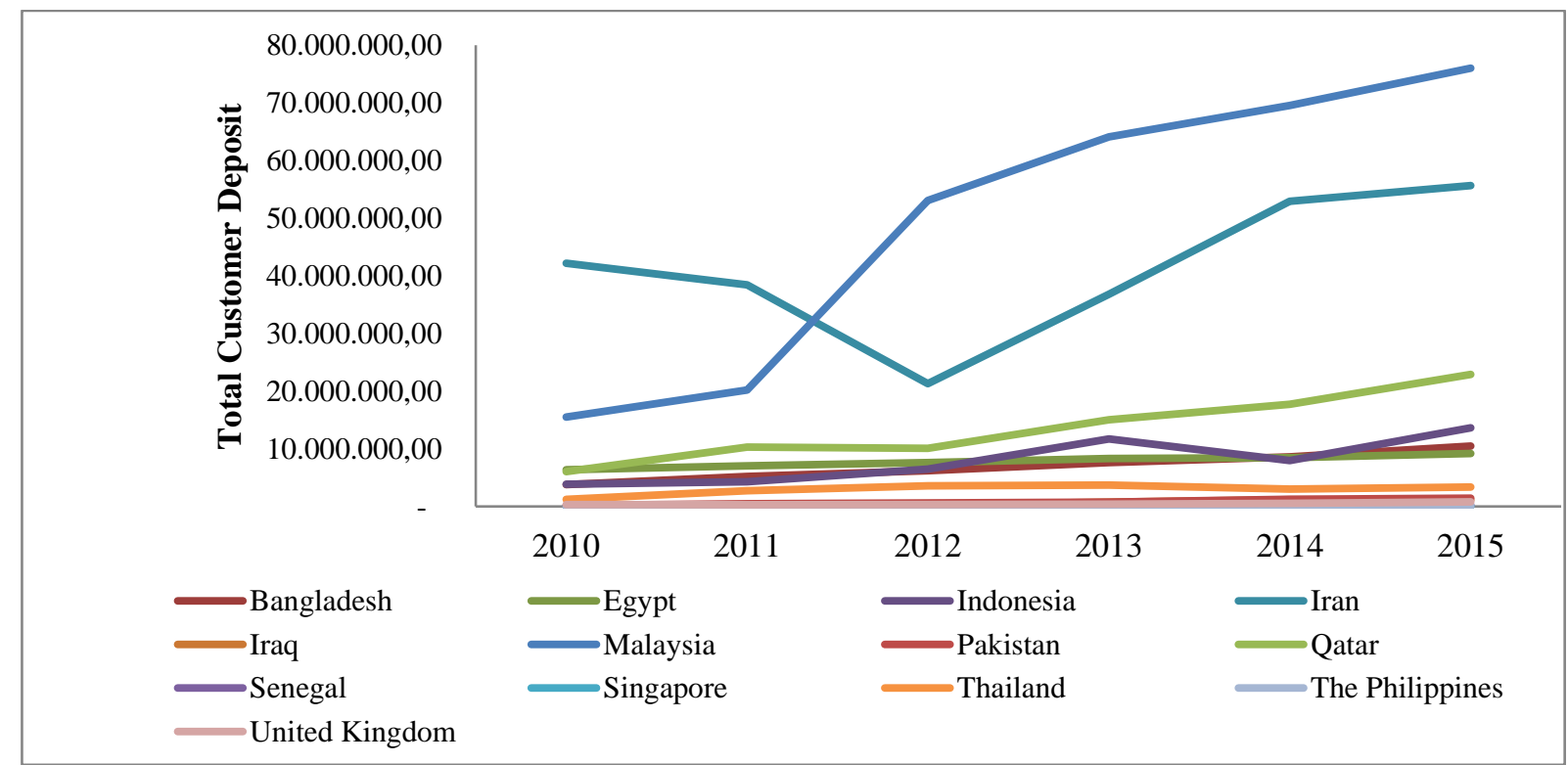

Source: Bankscope. Authors'calculation

Figure 3. Total Customer Deposits in 13 Selected Countries

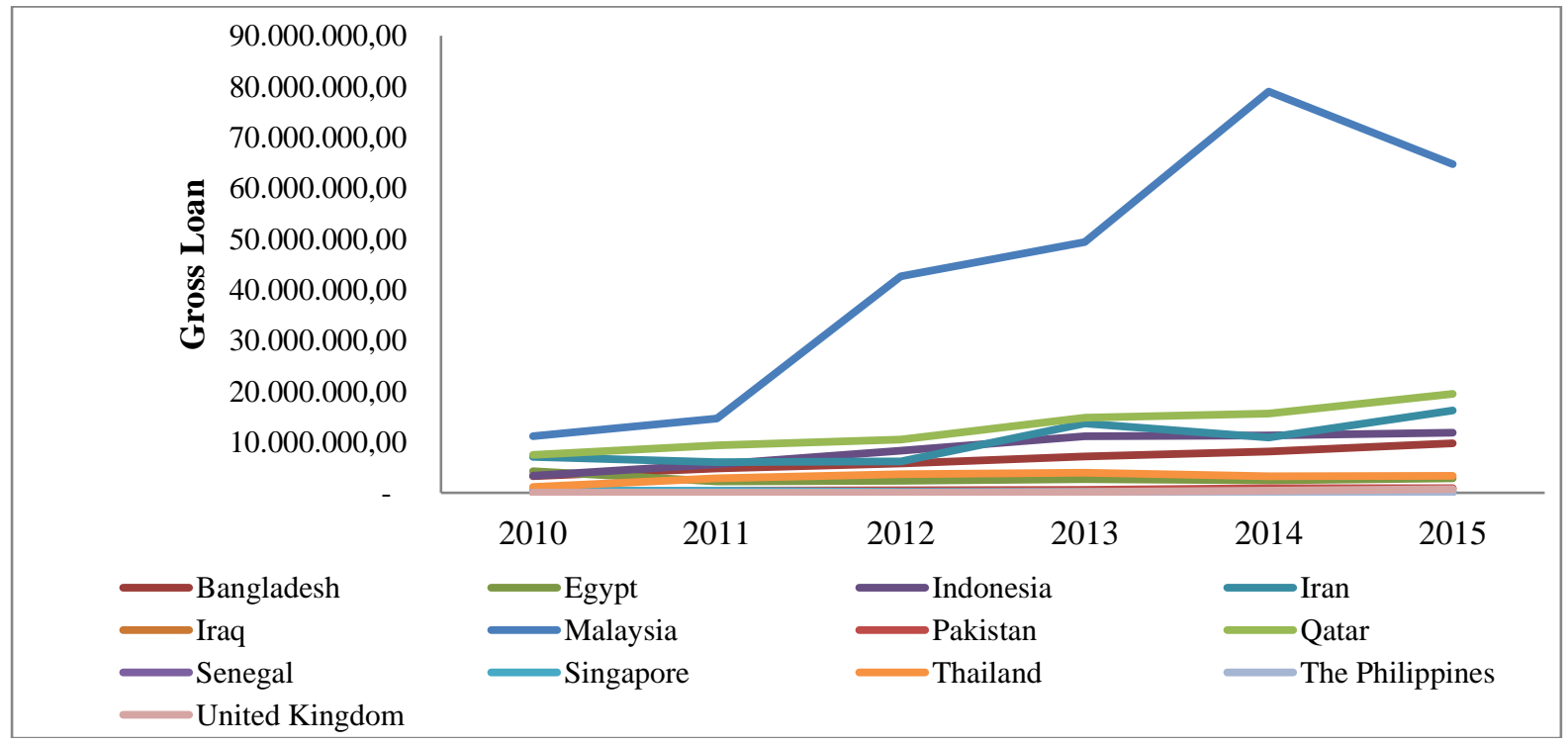

Source: Bankscope. Authors'calculation

Figure 4. Gross Loans in 13 Selected Countries 
$F S_{i t}$ variable measured by capital adequacy ratio play insignificant role on income inequality reduction. This might happen due to this research only cover short period and there is only few numbers of Islamic banks exist. Thus, the market share of Islamic bank is smaller than their counterpart. In this case, the negative coefficient of $F S_{i t}$ variable probably signs that Islamic banks may have role on income inequality reduction if the study period is longer (long term analysis). Recent empirical works studied by IMF staff show that in the long terms both income and wealth distribution is considered as the important contributor to economic stability (Berg and Ostry 2011; Berg, Ostry, and Zettelmeyer 2012; Kumhof, Rancière, and Winant 2015; Ostry, Berg, and Tsangarides 2014). The IMF Managing Director, Christine Lagarde even also said that the top condition to have more inclusive and sustainable economic growth is to maintain economic stability which needs to deal with the problem of inequality of income. Similarly, $I N F_{i t}$ variable have insignificant effect on Gini index. It might happen like $F S_{i t}$ which covers only short period. However, if we look at the sign, the relationship between inflation on income inequality might have negative impact, i.e. an increase of inflation level might have a considerable effect on widening income inequality.

In the other hand, GDPC $_{i t}$ variable measured by GDP per capita has positive impact on income inequality. p 5 shows that an increase in GDP per capita by $1 \%$, it will raise income inequality by about $0.1 \%$. Kuznet (1955) in this case explain the reason why an increase of GPD per capita might widen income inequality. Kuznets (1955) hypothesizes that inequality of income rises until reach a critical level of income and then inequality of income starts to decline. It implies that disparity of income will increase in the early stage of development; however, in the later stage disparity will decrease. This condition occurs when there is a shifting in the economic activity from rural areas to the city, for instance, farmers move to the city to get better paying-job. This migration hence yields in a wide rural-urban income gap and increases urban population, while in the same time the rural population decreases. Income gap, according to Kuznet (1955), is expected to decrease when a certain level of average income is attained. This condition is associated with the process of industrialization. Thus, the society is expected to get advantage from trickle-down effect which may effectively reduce income gap. Trickle-down effect refers to effect gained by the low-income group due to an increase in the income earned by the high-income group. Aghion and Bolton (1997) also supports the arguments that the addition wealth accrued by rich group is good for the poor due to some of the additional wealth of the rich trickles down to the poor.

\section{Conclusion}

The main characteristic of Islamic bank is the prohibition of riba (usury) in any transaction. It is thus expected that Islamic bank is able to promote fair income distribution. Islamic banks in the last two decades marked significant development. This condition can be observed at its assets, gross loans, total customer deposit and overhead cost. Based on the result above, it is empirically shown that the existence of Islamic banks may reduce income inequality represented by negative sign of financial depth. Islamic banks in this case may expand their business by opening branchless banking to develop its market up to sub-urban area. Even today technology supports the idea to open branchless banking service. Also, it is needed to educate more people, especially in the sub urban, on financial literacy in order to make understand the needs of Islamic banks on their economic transaction.

Other important finding should be highlighted is that the stability of Islamic bank must be maintained due to it has direct impact on income inequality. In many cases like what happened during Asia financial crisis in $1997 / 8$, the collapse of banking system harms socio economic as a whole. It means that the stability of banking system (including Islamic bank) has fundamental effect on economy.

\section{References}

Aghion, P., \& P. Bolton. (1997). A theory of trickle-down growth and development. The Review of Economic Studies, 64(2): 151-72.

Agnello, L., \& Sousa, R. M. (2012). How do banking crises impact on income inequality?. Applied Economics Letters, 19(15), 1425-1429.

Akimov, A., Wijeweera, A., \& Dollery, B. (2006). Finance-Growth Nexus: Evidence from Transition Economies. Economics Working Paper Series, 5.

Ayyagari, M., Beck, T., \& Hoseini, M. (2013). Finance and poverty: Evidence from India.

Baligh, N., \& Piraee, K. (2012). Financial development and income inequality relationship in Iran. Middle-East Journal of Scientific Research, 12(7), 906-914. 
Batuo, M. E., Guidi, F., \& Mlambo, K. (2010). Financial development and income inequality: Evidence from African Countries. African Development Bank, 1-28.

Berg, A. \& Ostry, J.D. (2011). Inequality and unsustainable growth: two sides of the same coin. International Monetary Fund Staff Discussion Note: 1-21.

Berg, A., Ostry, J.D., \& Zettelmeyer, J. (2012). What makes growth sustained. Journal of Development Economics, 98(2): 149-66.

Blair, M. M. (2010). Financial innovation and the distribution of wealth and income. Vanderbilt Law and Economics Research Paper, (10-22), 10-32. http://ssrn.com/abstract_id=1656451.

Bureau Statistic of Singapore. Retrieve from Singapore Departement of Statistic website http://www.singstat.gov.sg.

Bureau Statistic of Indonesia. Retrieve from Indonesia Central Bureau Statistic website http://www.bps.go.id.

Bureau Statistic of Malaysia. Retrieve from Department of Statistics Malaysia Official Portal http.//statistic.gov.my.

Cihák, M., Demirguc-Kunt, A., Feyen, E., \& Levine, R. (1960). Financial development in 205 economies. Journal of Financial Perspectives, EY Global FS Institute, 1(2), 17-36. http://www.nber.org/papers/w18946.

Elmi, Z. M. \& Ariani, F. (2011). Financial development and the distribution of income in MENA. Iranian Economic Review, 15(28): 1-11.

Hoi, C. M., \& Hoi, L. Q. (2012). Financial development and income inequality in vietnam: An empirical analysis. Journal of Economics and Development, 14(2), 5-25.

Jauch, S., \& Watzka, S. (2016). Financial development and income inequality: a panel data approach. Empirical Economics, 51(1), 291-314.

Kenourgios, D., \& Samitas, A. (2007). Financial development and economic growth in a transition economy: Evidence for Poland. Journal of Financial Decision Making, 3(1), 35-48.

Kumhof, M., \& Rancière, R. (2011). Leveraging inequality. International Journal of Labour Research, 3(2), 189.

K Kumhof, M., Rancière, R., \& Winant, P. (2015). Inequality, leverage, and crises. American Economic Review, 105(3), 1217-45.

Levine, R. (2003). More on finance and growth: more finance, more growth?. Review-Federal Reserve Bank of Saint Louis, 85(4), 31-46.

Liang, Z. (2006). Financial development and income distribution: a system GMM panel analysis with application to urban China. Journal of Economic Development, 31(2), 1..

Mohieldin, M., Iqbal, Z., Rostom, A., \& Fu, X. (2011). The role of Islamic finance in enhancing financial inclusion in Organization of Islamic Cooperation (OIC) countries. The World Bank, 20, 55-120.

D’Onofrio, A., \& Murro, P. (2013). Local banking development and income distribution across Italian provinces. Italian Economic Journal.

Organization for Economic and Cooperation Development (OECD). Income redistribution across OECD countries. Retrieve from OECD website http://www.oecd.org.

Ostry, M. J. D., Berg, M. A., \& Tsangarides, M. C. G. (2014). Redistribution, inequality, and growth. International Monetary Fund, 1-30.

P Park, D., \& Shin, K. (2017). Economic growth, financial development, and income inequality. Emerging Markets Finance and Trade, 53(12), 2794-2825.

Seven, U. \& Coskun, Y. (2016). Does financial development reduce income inequality and poverty? Evidence from emerging countries. Emerging Markets Review, 26, 34-63. http://linkinghub.elsevier.com/retrieve/pii/S1566014116300024.

Shahbaz, M. \& Islam, F. (2011). Financial development and income inequality in Pakistan: an application of 
ARDL approach. Journal of Economic Development, 36(1): 35-57.

Shahbaz, M., Loganathan, N., Tiwari, A. K., \& Sherafatian-Jahromi, R. (2015). Financial development and income inequality: Is there any financial Kuznets curve in Iran?. Social Indicators Research, 124(2), 357-382.

Standardized World Income Inequality Database (SWIID). Ineauqlity. Retrieve from SWIID website.

World Bank Data. World Development Indicator 2005. Retrieve from World Bank Data website http://data.worldbank.org/products/wdi.

Zhang, Q., \& Chen, R. (2015). Financial development and income inequality in China: An application of SVAR approach. Procedia Computer Science, 55, 774-781. http://dx.doi.org/10.1016/j.procs.2015.07.159. 